\title{
Selecting broilers for low or high abdominal fat : observations on the hens during the breeding period
}

\author{
B. LECLERCQ, J. SIMON \\ I.N.R.A., Station de Recherches avicoles \\ Centre de Recherches de Tours \\ Nouzilly, F 37380 Monnaie
}

\begin{abstract}
Summary
Laying hens of a lean line (LL) and a fat line (FL) were compared for laying performance, feed consumption, carcass composition and some plasma parameters. Both lines exhibited the same egg output and the same age at sexual maturity. The LL hens laid larger eggs with a significantly lower percentage of yolk. The LL hens were always heavier than FL ones although the abdominal fat was always higher in the FL. The body weight gain during the laying period was not significantly different between the lines. Both lines presented the same energy maintenance and feed efficiency for egg synthesis. The feed requirement for body weight gain was more pronounced in the FL birds but the difference was not significant. As in the immature birds, a different glucose-insulin balance was observed between lines. It is concluded that this persisting metabolic deviation may explain the tendancy of the $F \mathbf{L}$ to preferentially use feed energy for lipid synthesis of yolk or adipose tissue.
\end{abstract}

\section{Introduction}

Modern strains of broilers selected for a rapid growth rate very often exhibit excessive body fat deposition. This is particularly evident for the abdominal fat pad which is lost in the slaughter-house and represents an useless and expensive component in broiler production. A divergent selection programme was undertaken to reduce or increase this particular fat and the first observations of the study after 3 generations were reported by LECLERCQ, BLUM \& BoYER (1980). This selection programme was continued for another 2 generations. The results of the present paper deal with the correlated responses in laying performance and plasma components in the laying hens after 4 generations of selection for high fat line (FL) or low abdominal fat lean line (LL).

\section{Material and methods}

All the birds compared in this experiment belonged to the $F 4$ generation. Two hundred females of each line were mixed and brooded in a conventional floor 
pen. They were fed ad libitum three different diets according to age. The starter diet ( 0 to 21 days of age) contained 20.4 p. 100 protein and $3120 \mathrm{Kcal}$ M.E. $/ \mathrm{kg}$. The grower diet ( 21 to 63 days) contained 17.8 p. 100 protein and $3030 \mathrm{Kcal}$ M.E./kg. The pullet diet (64 to 175 days) contained 14.2 p. 100 protein and $2640 \mathrm{Kcal}$ M.E./kg. During the laying period the diet was formulated to contain 14.1 p. 100 protein and $2820 \mathrm{Kcal}$ M.E./ kg. Fifteen hours of light were provided until 9 weeks of age at which time the light period was reduced by one hour per day per week until, at 15 weeks of age, the photoperiod was $10 \mathrm{~L}: 14 \mathrm{D}$ (10 hours light : 14 hours dark). This light period was maintained until 19 weeks of age and then increased by one hour per day per week until 24 weeks of age. The photoperiod (15 L : 9 D) was then maintained constant throughout the laying period.

Twelve females of each line were slaughtered at 7, 14, 28, 63 and 119 days of age ; 29 birds of the LL and 34 of the FL were also slaughtered at 196 days. They were weighed and the abdominal fat was excised and weighed. The remaining birds were raised in individual cages. Their laying performance were observed until 308 days of age. The age a first egg, number of eggs, egg weight and live weight at 196 and 308 days were measured. Furthermore, the individual feed consumption was observed on seventy hens per line. Because of mortality and some hens going out of lay, the calculations were done on $59 \mathrm{LL}$ and $38 \mathrm{FL}$ hens. At 308 days of age 31 hens per line were slaughtered. The abdominal fat was excised and weighed. The remaining carcass of 9 birds per line were ground and kept for lipid analysis. The eggs laid at 294 days of age were broken and the yolks were weighed.

Plasma glucose and insulin were determined as previously described (ToucHBURN, Simon \& LECLERCQ, 1981). Non esterified fatty acids were measured according to the semi automatic method of FrUCHART et al. (1974). Total lipids were extracted by the Folch method from $5 \mathrm{ml}$ of plasma at 196 days of age and were weighed. Triglycerides and phospholipids were determined as a percentage of the total plasma lipid by TLC-FID using Iatroscan $\mathrm{H} 10$. Corrections were applied to the response of the flamme ionization detector using known standards of lecithin, tripalmitin, cholesterol and cholesterol palmitate. Total cholesterol was determined enzymaticaly using a BECKMAN auto-analyser (model 2).

Feed consumptions were compared between lines by the multiple linear regression using egg output and body weight change as independant variates. Regression coefficients were statistically compared according to Kendall \& STUART (1959).

\section{Results}

The mean values of live weight and the weight of the abdominal fat at different ages are given in table 1 . The body weights of the two lines were not statistically different until 63 days of age. Afterwards the pullets of the LL were significantly heavier than those of the FL. This difference remained significant even after 112 days of lay (table 2). The abdominal fat (table 1) was significantly more developped in the FL than in the LL at 14 days of age. This difference continued although it remained approximately constant in absolute value after 63 days of age.

The laying performances of all birds are reported in the table 2. Although the body weight of the hens of the LL was always higher than that of the FL the 
difference for the body weight change during the laying period was not significant. The age at first egg was not different. The total number of eggs laid from sexual maturity until 308 days of age was not different. The number of eggs laid for 196 to 308 days of age was slightly but significantly higher for the FL birds. The eggs were heavier in the LL. This difference was significant by either analysis of variance or analysis of covariance using live weight as the covariate. The total egg output during the 112 experimental days was the same in both lines. The relationship between egg weight and egg yolk is illustrated in figure 1. The slope of the regression lines were different between the lines. The yolk percentage was significantly higher in the eggs of the FL hens.

TABLE 1

Body weight and abdominal fat of the pullets of the lean line (LL) and fat line (FL) according to the age.

Poids vif et poids du dépôt adipeux abdominal chez les poulettes en fonction de l'âge.

\begin{tabular}{|c|c|c|c|}
\hline Age (days) & $\mathbf{L L}^{*}$ & FL & $\begin{array}{l}\text { Statistical } \\
\text { sonificonce }\end{array}$ \\
\hline 7 body weight $(g) \ldots \ldots$ & $83 \quad(2.3) * *$ & (3.1) & NS \\
\hline $\begin{array}{l}14 \text { body weight }(\mathrm{g}) \ldots \ldots \\
\text { abdominal fat }(\mathrm{g}) \ldots \ldots\end{array}$ & $\begin{aligned} 183 & (6.7) \\
0.9 & (0.12)\end{aligned}$ & $\begin{aligned} 183 & (4.8) \\
1.62 & (0.24)\end{aligned}$ & $\begin{aligned} & \text { NS } \\
& \mathrm{p}<0.05\end{aligned}$ \\
\hline $\begin{array}{r}28 \text { body weight }(g) \ldots \ldots \\
\text { abdominal fat }(g) \ldots \ldots\end{array}$ & $\begin{array}{r}529(13.7) \\
6.3(0.57)\end{array}$ & $\begin{array}{l}552 \\
13.2\end{array}$ & $\begin{array}{c}\text { NS } \\
\mathrm{p}<0.01\end{array}$ \\
\hline $63 \begin{array}{l}\text { body weight }(\mathrm{g}) \quad \ldots \ldots \\
\text { abdominal fat }(\mathrm{g}) \ldots \ldots\end{array}$ & $\begin{aligned} 1859 & (74) \\
35.2 & (3.6)\end{aligned}$ & $\begin{array}{r}1756 \\
79.1\end{array}$ & $\begin{array}{c}\text { NS } \\
\mathrm{p}<0.01\end{array}$ \\
\hline $\begin{array}{l}119 \text { body weight }(\mathrm{g}) \ldots \ldots \\
\text { abdominal fat }(\mathrm{g}) \ldots \ldots\end{array}$ & $\begin{array}{ll}2950 & (117) \\
116.8 & (9.8)\end{array}$ & $\begin{array}{l}2783 \\
179.6\end{array}$ & $\begin{array}{l}\mathrm{p}<0.05 \\
\mathrm{p}<0.01\end{array}$ \\
\hline $\begin{array}{l}196 \text { body weight }(\mathrm{g}) \\
\text { abdominal fat }(\mathrm{g})\end{array}$ & $\begin{array}{ll}3651 & (80) \\
180.2 & (13.2)\end{array}$ & $\begin{array}{l}3300 \\
227.6\end{array}$ & $\begin{array}{l}\mathrm{p}<0.05 \\
\mathrm{p}<0.01\end{array}$ \\
\hline $\begin{array}{l}\text { (*) } \mathrm{LL}=\text { lean line; } \mathrm{FL}= \\
(* *) \text { Standard error. }\end{array}$ & line. & & \\
\hline
\end{tabular}

The feed consumption and laying performance of the feed controlled hens are given in table 3. Feed consumption was greater in the LL. Multiple regression analysis was performed for both lines between feed consumption, egg output and body weight change divided by body weight. The following equations were obtained :

$\mathrm{FL} \quad \mathrm{F} / \mathrm{W}=29.15( \pm 1.89)+.75( \pm .18) \mathrm{E} / \mathrm{W}+4.76( \pm .46) \Delta \mathrm{W} / \mathrm{W}$
$\mathrm{R}^{2}=.77$
$\mathrm{LL} \quad \mathrm{F} / \mathrm{W}=29.81( \pm 2.18)+.88( \pm .14) \mathrm{E} / \mathrm{W}+2.91( \pm .37) \Delta \mathrm{W} / \mathrm{W}$
$\mathrm{R}^{2}=.66$ 
Where $F$ is the feed consumption in $\mathrm{g} . \mathrm{d}^{-1}, \mathrm{~W}$ the body weight in $\mathrm{kg}, \mathrm{E}$ the egg output in $\mathrm{g} . \mathrm{d}^{-1}, \Delta \mathrm{W}$ the daily body weight change in $\mathrm{g}$. The values inside the brackets are the standard error. No significant difference was evident between the lines for the different coefficients of the equation suggesting that the feed requirement for maintenance, egg synthesis and body gain are identical in the two lines.

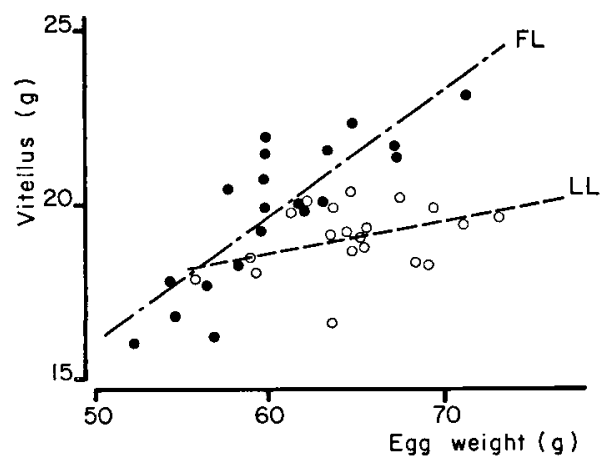

FIG. 1

Relationship between egg weight and yolk weight at 294 days of age in the fat line (•) and the lean line $(\mathrm{O})$.

(non parallelism test significant $[F=12.2]$ )

Relations entre poids de l'œuf et poids du jaune chez les poules âgées de 294 jours.

\section{TABLE 2}

Body weight and laying performance of both lines until 308 days of age.

Poids vif et performances de ponte des poules jusqu'à l'âge de 308 jours.

\begin{tabular}{|c|c|c|c|}
\hline & $\mathbf{L} L^{*}$ & FL & $\begin{array}{l}\text { Statistical } \\
\text { significance }\end{array}$ \\
\hline Number of hens $\ldots \ldots \ldots \ldots$ & 70 & 86 & \\
\hline Body weight at 196 days $(\mathrm{g})$ & $(53.6)^{* k \cdot k}$ & $(41.6)$ & $\mathrm{p}<0.01$ \\
\hline Body weight at 308 days (g) & $(59.0)$ & 3935 & $\mathrm{p}<0.01$ \\
\hline Body weight change $(g) \ldots \ldots$ & $(38.8)$ & $231 \quad(29.7)$ & NS \\
\hline Age at first egg (d) $\ldots \ldots \ldots$ & $184.0(1.1)$ & $186.3(1.7)$ & NS \\
\hline Total number of eggs ..... & $80.4(2.1)$ & $83.2(1.6)$ & $\mathrm{p}<0.05$ \\
\hline $\begin{array}{l}\text { Eggs laid between } 196 \text { and } \\
308 \mathrm{~d} \ldots \ldots \ldots \ldots \ldots\end{array}$ & $68.4(1.7)$ & $71.8(1.2)$ & $\mathrm{p}<0.01$ \\
\hline $\begin{array}{r}\text { Egg output between } 196 \text { and } \\
308 \text { days }(g) \ldots \ldots \ldots \ldots\end{array}$ & 4173 & 4165 & NS \\
\hline
\end{tabular}

(*) $\mathrm{LL}=$ lean line $; \mathrm{FL}=$ fat line.

(**) Standard error. 


\section{TABLE 3}

Feed consumption and laying performance of hens of the $L L$ and $F L$.

Consommation et performances de ponte chez les poules des lignées maigre et grasse.

\begin{tabular}{l|c|c|c}
\hline & LL* & FL & $\begin{array}{c}\text { Statistical } \\
\text { significance }\end{array}$ \\
\hline Number of hens $\ldots \ldots \ldots$ & 59 & 38 & \\
Body weight at 196 days $(\mathrm{g})$ & 3857 & 3647 & $\mathrm{p}<0.01$ \\
Body weight change $(\mathrm{g} / \mathrm{d}) \ldots$ & 1.60 & 1.77 & $\mathrm{NS}$ \\
Egg output $(\mathrm{g} / \mathrm{d}) \ldots \ldots \ldots \ldots$ & 37.7 & 37.1 & $\mathrm{NS}$ \\
Feed consumption (g/d) $\ldots .$. & 153.1 & 143.1 & $\mathrm{p}<0.05$ \\
\hline
\end{tabular}

$(*) \quad L L=$ lean line; $F L=$ fat line.

The relationship between abdominal fat, the remaining lipids (extra abdominal fat) and body weight at 196 and 308 days are shown in table 4. The correlation between abdominal fat and extra abdominal fat was always high except for the FL birds at 196 days. The coefficients of regressions between these traits in the two lines were never significantly different but the test of non parallelism is always very close to the level of 5 p. 100 ( $F=3.7$ at 196 days and 3.2 at 308 days). The regression lines between abdominal fat and extra abdominal fat were always significantly different $(F=11.9$ at 196 days and 7.1 at 308 days). This difference is illustrated in figure 2 .

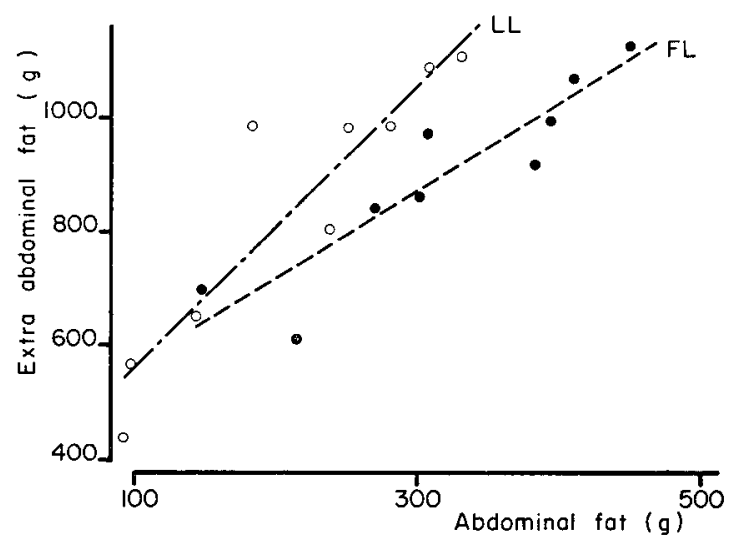

FIG. 2

Relationship between abdominal fat and extra-abdominal fat of hens at the age of 308 days in the fat line (-) and the lean line (O).

Relations entre dépôt adipeux abdominal et lipides extra-abdominaux chez les poules à l'âge de 308 jours. 
TABLE 4

Relationships between body weight $(B W)$, abdominal fat $(A F)$ and extra-abdominal fat (EAF) of hens at 196 and 308 days of age.

Relations entre le poids vif, le dépôt adipeux abdominal et les lipides extra-abdominaux chez les poules âgées de 196 et 308 jours.

\begin{tabular}{|c|c|c|c|c|}
\hline Age & Line & No. birds & Equations & $\begin{array}{l}\text { Coefficient } \\
\text { of correlation }\end{array}$ \\
\hline \multirow[t]{6}{*}{196 days } & & & & \\
\hline & LL & 10 & $\mathrm{EAF}=2.723 \mathrm{AF}+327$ & .760 \\
\hline & & $\begin{array}{l}29 \\
10\end{array}$ & $\begin{array}{l}\mathrm{AF}=.108 \mathrm{BW}-180 \\
\mathrm{EAF}=.337 \mathrm{BW}-326\end{array}$ & $\begin{array}{l}.804 \\
870\end{array}$ \\
\hline & FL & 10 & $\mathrm{EAF}=.798 \mathrm{AF}+572$ & .440 \\
\hline & & 34 & $\mathrm{AF}=.133 \mathrm{BW}-156$ & .689 \\
\hline & & 10 & $\mathrm{EAF}=.273 \mathrm{BW}-136$ & .752 \\
\hline \multirow{7}{*}{308 days } & & & & \\
\hline & LL & 9 & $\mathrm{EAF}=2.474 \mathrm{AF}+320$ & .899 \\
\hline & & 31 & $\mathrm{AF}=.124 \mathrm{BW}-232$ & .782 \\
\hline & & 9 & $\mathrm{EAF}=.418 \mathrm{BW}-723$ & .926 \\
\hline & $\mathrm{FL}$ & 9 & $\mathrm{EAF}=1.547 \mathrm{AF}+409$ & .906 \\
\hline & & 31 & $\mathrm{AF}=.169 \mathrm{BW}-313$ & .660 \\
\hline & & 9 & $\mathrm{EAF}=.293 \mathrm{BW}-205$ & .686 \\
\hline
\end{tabular}

$\mathrm{BW}, \mathrm{AF}$ and EAF are expressed in $\mathrm{g}$.

At 196 days of age mean abdominal fat weight was $242 \mathrm{~g}$ for $\mathrm{LL}$ and $337 \mathrm{~g}$ for FL.

At 308 days the values were respectively $276 \mathrm{~g}$ and $352 \mathrm{~g}$.

The mean values of plasma glucose, insulin, non esterified fatty acids (NEFA), triglycerides (TG), cholesterol and phospholipids at 196 days are presented in table 5 . In the fed state, no difference was found between lines. In the starved state, plasma glucose level was lower in the FL hens. Starvation had no significant effect on any of these plasma parameters in the lean birds. By contrast starvation lowered the plasma concentration of glucose and insulin in the FL hens.

\section{Discussion}

Selecting 9 week-old male broilers for low or high abdominal fat also induced a difference, although less marked, for this parameter in the females (LEcLERcQ, BLUM \& BOYER, 1980). The divergence between lines was maximum at 63 days of age. Thereafter, the changes in abdominal fat were quite similar in both lines as may be seen from our present results. During the adult period a significant difference persisted in the amount of abdominal fat. However, the fat depots in other regions 
TABLE 5

Plasma glucose, insulin and lipids of starved and fed hens at 189 days of age. Concentrations des plasmas en glucose, insuline et lipides à l'âge de 189 jours.

\begin{tabular}{|c|c|c|c|}
\hline & LL & FL & $\begin{array}{c}\text { Statistical } \\
\text { difference } \\
\text { between lines }\end{array}$ \\
\hline \multicolumn{4}{|l|}{ Fed } \\
\hline Number of birds $\ldots \ldots \ldots$. & 11 & 10 & \\
\hline Glucose $(\mathrm{mg} / \mathrm{ml})$ & $2.04(0.04)$ & $1.96(0.03)$ & NS \\
\hline Insulin $(\mathrm{ng} / \mathrm{ml}) \ldots \ldots$ & $1.73(0.21)$ & $1.58(0.26)$ & NS \\
\hline $\begin{array}{l}\text { Non esterified fatty acids } \\
\qquad(\mu \mathrm{g} / \mathrm{ml}) \ldots \ldots \ldots \ldots \ldots \ldots\end{array}$ & $460 \quad(42)$ & $348 \quad(42)$ & NS \\
\hline Triglycerides $(\mathrm{mg} / \mathrm{ml}) \ldots \ldots$ & $17.06(2.24)$ & $17.57(3.26)$ & NS \\
\hline Phospholipids (mg/ml) ..... & $7.09(0.76)$ & $8.95(1.01)$ & NS \\
\hline Total cholesterol $(\mathrm{mg} / \mathrm{ml}) \ldots$ & $1.71(0.12)$ & $2.09(0.15)$ & NS \\
\hline \multicolumn{4}{|l|}{ Starved } \\
\hline Number of birds $\ldots . .$. & 11 & 10 & \\
\hline Glucose $(\mathrm{mg} / \mathrm{ml}) \ldots \ldots \ldots$ & $1.94(0.04)$ & $1.77(0.03)$ & $\mathrm{p}<0.01$ \\
\hline Insulin $(\mathrm{ng} / \mathrm{ml})$ & $1.30(0.19)$ & $0.77(0.17)$ & NS \\
\hline $\begin{array}{l}\text { Non esterified fatty acids } \\
\qquad(\mu \mathrm{g} / \mathrm{ml}) \ldots \ldots \ldots \ldots\end{array}$ & $422 \quad(19)$ & $468 \quad(56)$ & NS \\
\hline Triglycerides $(\mathrm{mg} / \mathrm{ml})$ & $12.49(2.20)$ & $16.46(4.50)$ & NS \\
\hline P'hospholipids $(\mathrm{mg} / \mathrm{ml}) \ldots \ldots$ & $8.56(1.35)$ & $8.33(1.76)$ & NS \\
\hline Total cholesterol $(\mathrm{mg} / \mathrm{ml}) \ldots$ & $1.85(0.18)$ & $1.76(0.16)$ & NS \\
\hline \multicolumn{4}{|l|}{$\begin{array}{l}\text { Statistical difference between } \\
\text { nutritional status }\end{array}$} \\
\hline Glucose $\ldots \ldots \ldots \ldots \ldots$. & NS & $\mathrm{p}<0.01$ & \\
\hline Insulin $\ldots \ldots \ldots \ldots \ldots \ldots$ & NS & $\mathrm{p}<0.05$ & \\
\hline Non esterified fatty acids .... & NS & NS & \\
\hline Triglycerides .... & NS & NS & \\
\hline Phospholipids $\ldots \ldots \ldots$ & NS & NS & \\
\hline Total cholesterol & NS & NS & \\
\hline
\end{tabular}


of the body were equal in both lines. The regression between abdominal fat and extra abdominal fat was the same in both lines in the F 2 generations birds (LECLERCQ, BLUM \& BoyER, 1980), although in this F 4 generation the regression lines were significantly different in adults at 196 days as in the broiler males at 7 weeks of age (Leclerce \& SaAdoun, unpublished). It may be thought that selection not only influenced general metabolic and hormonal but also anatomical characteristics as the number of preadipocytes or vascularisation of the abdominal fat. During the 112 days laying period, body weight change was not significantly different between lines, although it was higher in FL hens. Calculations made by applying the regression equations found in table 4 to the means of the experimental flock (table 2) shows that the increase in abdominal fat was equal to $+34 \mathrm{~g}$ in $\mathrm{LL}$ and $+15 \mathrm{~g}$ in FL. The change in extra abdominal fat during the laying period was $-2 \mathrm{~g}$ in $\mathrm{LL}$ and $+72 \mathrm{~g}$ in FL. Lipids represented $17 \mathrm{p} .100$ of the body weight gain $(32 / 187)$ in LL and 42 p. $100(97 / 229)$ in the FL hens. Therefore, although not significant, the tendency of fat birds to deposit more lipids still persists during the laying period but the rate of deposition is lower than that observed during the growing period (table 1). This conclusion is also supported by the feed efficiency data. As may be seen in the regression equations more feed is required for $1 \mathrm{~g}$ of body weight gain in FL than in LL hens (4.76 vs 2.91). Although this difference was not significant it agrees well with the conclusion that the FL hens deposit more lipid in the adipose tissue.

The selection for the different levels of abdominal fat induced no difference in sexual maturity. The total egg output was not influenced by the divergence of the lines. However, FL hens produced eggs with a higher yolk percentage and consequently very likely exported more lipids in their eggs.

According to the feed efficiency results, no difference was found for the maintenance requirement. This is in good agreement with our observations in young immature birds (LECLERCQ \& SAADOUN, 1982). The difference in adiposity between the selected lines cannot be accounted for by a difference in the energy requirement for maintenance. The higher feed consumption of the LL hens is mainly a result of the higher live weight of these birds.

In previous studies on immature LL or FL chickens (Touchburn, Simon \& LECLERCQ, 1981 ; SIMON \& LeCLERCQ, 1982), a slight impairment of the glucose-insulin balance was found. In fed as in starved birds the plasma concentration of glucose was lower in FL than in LL chickens, although plasma insulin concentration did not differ. By contrast after a glucose load the change in the plasma concentration of glucose with time was identical in both lines but plasma insulin reached consistently higher levels in FL. In adult hens, the present results show that in the starved state the plasma concentration of glucose was still lower in FL than in LL hens and that the plasma insulin remained at the same concentration in both lines. Other plasma parameters did not differ between the lines. Lastly as previously observed in several studies (RIIS, 1972; LECLERCQ et al., 1979) the plasma concentration of non esterified fatty acids was not increased by fasting in the laying hen.

In conclusion, the difference in energy metabolism and in its regulation found in immature chicken of this LL and FL can still be observed during the reproductive period of the female. These differences are less pronounced during the laying period but they indicate that the hens of the FL continue to preferentially use feed energy above maintenance for fat deposition and yolk synthesis, i.e. lipid synthesis.

\section{Accepté pour publication en mars 1982.}




\section{Acknowledgements}

The authors wish to acknowledge Bernadette Chevalier, Michel Derouet, Gérard Guy, Serge Nevoit et Marie-Rose Salichon for their invaluable assistance. B. Etches supervised the English translation.

A part of this work was financially supported by the grant «Mobilisation des Réserves» from I.N.R.A.

\section{Résumé}

La sélection divergente du poulet sur le dépôt adipeux abdominal : conséquences sur les performances de ponte et quelques paramètres sanguins des femelles adultes

On compare les performances et quelques paramètres sanguins de poules reproductrices issues de deux lignées expérimentales sélectionnées sur leur état d'engraissement à l'âge de 9 semaines. Les poules des deux lignées présentent la même maturité sexuelle et produisent la même masse d'œufs. Les poules de la lignée maigre tendent à pondre un peu moins d'oufs mais ceux-ci sont significativement plus lourds et présentent une teneur plus faible en jaune. Les poules de la lignée grasse sont plus légères mais possèdent un dépôt adipeux abdominal plus important que la lignée maigre. Le gain de poids vif est plus important chez les poules grasses mais cette différence n'est pas significative. Ni le besoin énergétique d'entretien, ni l'efficacité de la synthèse de l'œuf ne diffèrent entre les deux lignées. La quantité d'aliment nécessaire à la croissance est plus importante dans la lignée grasse sans que la différence ne soit significative. Dans le plasma, on observe un équilibre glucose-insuline différent dans chaque lignée. Ce phénomène qui existe déjà chez l'animal immature persiste donc chez la femelle en reproduction. Il expliquerait pourquoi chez l'adulte de la lignée grasse comme chez le jeune la synthèse de lipides (vitellus et tissus adipeux) continue d'être plus importante que dans la lignée maigre.

\section{References}

Fruchart J.C., Dewallly P., Jaillard J., Sezille G., 1974. Dosage colorimétrique semiautomatique des acides gras. Ann. Biol. Clin., 32, 237-244.

Kendall M.G., Stuart A.S., 1959. Partial and multiple correlation and regression. In : The avanced theory of statistics, t. II, 330-360. C. GRIFFIN Ed., London.

Leclerce B., Salichon M.R., Guillaumin S., Blum J.C., 1979. The role of VLDL in the transport of non esterified fatty acids in the laying hen. Comp. Biochem. Physiol., 62 A, 577-578.

Leclerce B., Blum J.C., Boyer J.P., 1980. Selecting broilers for low or high abdominal fat : initial observations. Brit. Poult. Sci., 21, 107-113.

Leclerce B., SAadoun A., 1982. Selecting broilers for low or high abdominal fat : comparison of energy metabolism of the lean and fat lines. Poult. Sci. (in press).

Rirs P.M.. 1972. Glucose and fatty acid metabolism in laying hens. Acta agric. Scand., 22, 209-217.

Simon J., LECLERCQ B., 1982. Longitudinal study of adiposity in chickens selected for high or low abdominal fat content. Further evidence of a glucose-insulin imbalance in the fat line (in preparation).

Touchburn S., Simon J., Eeclerce B., 1981. Evidence of a glucose insulin imbalance and effect of dietary protein and energy level in chicken selected for high abdominal fat content. I. Nuir., 111, 325-335. 